\title{
Perbandingan Sistem Pinjaman IMF dan Brics New Development Bank serta Potensi Dominasi Sistem Moneter Internasional
}

\author{
Mahendra Lantang Pamungkas, Riswanti Dyah Sekar Rahayu, \\ Trieska Ayu Krisyanti
}

Prodi Ilmu Hubungan Internasonal, Universitas Muhammadiyah Malang - Indonesia

Email: lantangpamungkas@ymail.com

Diserahkan: 24 Juni 2019 |Diterima: 28 Desember 2019

\begin{abstract}
America is the dominant power for a long time since the World War and gave many aid for many state developments in the world with their 'Marshall Plan' policy. America domination clarified by the existence World Trade Organization. United States of America legitimation not only limited to WTO, there are several international economic organizations such as World Bank and International Monetary Fund where the America hold an important power. Countries that want to compete with America legitimacy establish an organization called BRICS. BRICS consist of Brazil, Russia Federation, India, China, and South Africa. BRICS created a bank called BRICS NDB or National Development bank to compete IMF domination. This research will explain the differentiation between IMF and NDB, alongside with how NDB have capability to compete IMF as an international bank that give loans to countries. This research uses descriptive comparative method, so this research will have focused on comparation between the two banks. Analysis on this research will use Structural Power Theory with Middle Power concept to explain IMF domination and how NDB that created by Middle Powered countries can replace IMF domination.
\end{abstract}

Keywords: IMF, BRICS NDB, Monetary, International, Economy.

\begin{abstract}
Abstrak
Amerika adalah kekuatan dominan sejak Perang Dunia dan telah memberikan banyak bantuan dalam pembangunan negara-negara yang ada di dunia dengan menggunakan kebijakan 'Marshall Plan' nya. Hegemoni Amerika Serikat diperjelas dengan adanya World Trade Organization (WTO). Legitimasi kekuasaan Amerika Serikat tidak sebatas WTO saja, tetapi juga di organisasi internasional seperti World Bank dan Interational Monetary Fund (IMF). Negara-negara yang ingin menyaingi legitimasi Amerika membentuk organisasi perbankan yang anggotanya terdiri dari Brazil, Rusia, India, China dan South Africa. Tujuan dari BRICS adalah untuk menyaingi dominasi IMF. Penelitian ini akan membandingkan antara IMF dan BRICS NDB serta potensi NDB menggantikan IMF sebagai bank internasional yang selama ini memberikan pinjaman kepada banyak negara. Penelitian ini menggunakan metode deskriptif komparatif yang membandingkan kedua bank. Analisis dalam penelitian ini akan menggunakan Structural Power Theory dengan konsep Middle Power untuk menjelaskan bagaimana dominasi IMF dan bagaimana NDB yang dibentuk oleh negara - negara dengan kekuatan middle power dapat menggantikan dominasi IMF.
\end{abstract}

Kata Kunci : IMF, BRICS NDB, Moneter, Internasional, Ekonomi.

\section{PENDAHULUAN}

Hegemoni adalah suatu hal yang tidak dapat dipungkiri, baik dalam dunia politik maupun dunia ekonomi.
Dapat dilihat dari berakhirnya perang dunia kedua, nama Amerika Serikat semakin besar. Sebagai salah satu 
negara yang mengalami sedikit kerugian perang, Amerika Serikat begitu giat memberikan bantuanbantuan ekonomi kepada negara lain, terlebihnya kepada negara-negara Eropa Barat yang memang mengalami banyak kerugian. Bantuan terhadap Eropa Barat ini disebut dengan Marshall Plan. Melalui program ini, Amerika Serikat mambangun namanya sebagai negara yang membantu Eropa untuk hidup lagi. Dalam program ini, Amerika Serikat mengucurkandana sebesar 13 miliar dolar atau sekitar Rp 179 triliun yang hari ini kira-kira setara dengan Rp 1.500 triliun (Hardoko, 2018). Berjalannya Marshall Plan ini juga sebagai salah satu latar belakang mengapa mata uang Dollar Amerika Serikat dijadikan patokan currency mata uang sedunia. Hal ini juga menandai berhasilnya Amerika Serikat membangun namanya dan menguasai perekonomian di dunia.

Selain Marshall Plan, ada juga yang namanya GATT/WTO. World Trade Organization merupakan satu-satunya organisasi internasional yang mengatur secara khusus perdagangan antar negara. WTO saat ini adalah rezim penguasa perdagangan internasiona, yang berhak menghukum negara anggotanya yang melanggar perjanjianperjanjian serta peraturan yang sudah disepakati. Salah satu pencetus didirikannya WTO tentu saja Amerika Serikat, dan sampai sekarang pun
Amerika Serikat tetap memiliki pengaruh yang sangat kuat terhadap WTO. Pernyataan bahwa WTO sebagai rezim penguasa perdagangan internasinal, dengan kata lain menyatakan bahwa penguasa perdagangan internasional sebenarnya adalah Amerika Serikat.

Atas hegemoni Amerika Serikat yang begitu kuat terhadap perekonomian dunia, beberapa negara industri membentuk suatu organisasi ekonomi, yang bertujuan untuk melepaskan diri dari pengaruh hegemoni tersebut. Beberapa negara yang bergabung adalah Brasil, Rusia, India, Cina, dan Afrika Selatan atau biasa disebut BRICS. Bergabungnya negara-negara tersebut adalah dikarenakan adanya ketidakadilan dan berbedaan prinsip dengan World Bank dan International Monetary Fund, yang mana keduanya dikuasai oleh Amerika Serikat. Negara-negara yang tergabung dalam BRICS terhitung sangat vokal dalam menyuarakan ketidaksetujuannya dengan kebijakankebijakan yang dikeluarkan World Bank dan/atau IMF. BRICS menganggap dominansi World Bank dan IMF sangat berpihak kepada negara-negara yang banyak memodalinya, sehingga mengakibatkan ketimpangan dalam proses pembuatan kebijakan, dan hal tersebut dinilai sangat merugikan bagi negara-negara dunia ketiga. 


\begin{tabular}{lcr}
\multicolumn{1}{c}{ Salah satu tindakan } & yang \\
dilakukan & BRICS & dalam \\
mengembalikan & keseimbangan \\
perekonomian & dunia & adalah \\
dibentuknya & BRICS & Development
\end{tabular}
Bankatau yang baru-baru ini diganti namanya menjadi New Development Bank. NDB sendiri adalah sebuah bank pembangunan multilateral yang akan dijalankan oleh negara-negara anggota BRICS yaitu Brasil, Rusia, India, Cina, dan Afrika Selatan. New Development Bank disepakati pada pertemuan KTTT BRICS yang kelima pada tanggal 27 Maret 2013 di Durban, Afrika Selatan (Powell, 2013). Pada KTT BRICS keenam, negara-negara anggota BRICS menandatangani dokumen pembentukan BRICS Development Bank seniali $\$ 100$ Miliar dan cadangan mata uang tambahan senilai \$100 Miliar (Bbc, 2014). Presiden pertama yang terpilih adalah berasal dari India. Berdasarkan hal yang telah disebutkan sebelumnya, maka dari itu dalam penelitian ini penulis akan meneliti tentang bagaimana perbedaan pengambilan kebijakan antara BRICS National Development Bank dengan IMF.

\section{METODE}

Dalam rangka menjelaskan perbandingan antara institusi IMF dan BRICS New Development Bank penulis menggunakan tingkat analisa sistem internasional. Tingkat analisa Sistem
Internasional adalah dimana negaranegara di dunia saling berinteraksi membentuk suatu sistem. Struktur sistem dan perubahan yang dialaminya akan menentukan perilaku aktor-aktor Hubungan Internasional yang terlibat di dalamnya. Sistem yang berlaku dalam suatu wilayah akan mempengaruhi perilaku negara-negara di sistem tersebut.

Metode yang digunakan adalah metode deskriptif komparatif. Penelitian deskriptif bertujuan mencapai fakta dengan menginterpretasikan data secara tepat. Dengan metode deskriptif peneliti dapat membandingkan berbagai fenomena sehingga menjadi studi komparatif. (Mas'oed, 1995) Dengan menggunakan metode penelitian deskriptif komparatif maka peneliti akan menyampaikan penjelasan secara menyeluruh mengenai hasil penelitian, di mana di dalamnya dijelaskan secara naratif sehingga diharapkan temuan penelitian merupakan temuan yang obyektif.

Teknik pengumpulan data dalam penelitian ini yaitu studi pustaka yang menggunakan data sekunder, yaitu data-data yang diambil secara tidak langsung di lapangan. Data yang diperoleh dengan memahami dan mempelajari dari literatur-literatur, majalah, artikel, internet, hasil penelitian terdahulu dan karya ilmiah yang berhubungan dengan 
permasalahan yang diangkat oleh penulis. Pengumpulan data tersebut diteruskan dengan pengolahan data serta menyeleksi dan mengklasifikasikan data yang relevan dengan objek penelitian. Teknik analisis data yang digunakan dalam penelitian ini adalah analisis data kualitatif. Dalam hal ini teknik analisis data melalui proses mencari dan menyusun secara sistematis data yang diperoleh dari hasil studi pustaka, sehingga mudah dipahami, dan temuannya dapat diinformasikan kepada orang lain.

\section{KERANGKA TEORI}

Dalam penelitian ini, penulis menggunakan structural power theory untuk menjelaskan perbedaan antara IMF sembagai lembaga Brettonwoods yang telah mendominasi sistem finansial dan moneter internasional dalam waktu yang lama dibandingkan dengan BRICS NDB (Culpepper, 2015). Di dalam sumber yang sama disebutkan pula bahwa hubungan antara negara dengan bisnis terikat dalam hubungan saling ketergantungan, dimana ketergantungan tersebut dapat membawa sebuah resiko (Culpepper, 2015). Menurut Susan Strange structural power dalam ekonomi politik internasional memiliki empat dimensi yaitu keamanan, produksi, keuangan dan pengetahuan (May,
2008). Oleh karena itu, dalam penelitian ini teori tersebut digunakan untuk menjelaskan kekuatan struktural yang terdapat pada Lembaga Brettonwoods yaitu IMF dan BRICS New Development Bank yang lalu dibandingkan diantara keduanya.

Selain menggunakan structural power theory dalam menjelaskan perbandingan antara IMF dan BRICS New Development Bank, penulis juga menggunakan konsep middle power. Middle power adalah negara yang tidak besar maupun tidak kecil dalam hal kekuatan, kapasitas dan pengaruh internasional, namun memiliki kecenderungan untuk mempromosikan kohesi dan stabilitas dalam sistem dunia (Jordaan, 2003). Konsep Middle Power juga mengatakan bahwa negara yang memiliki middle power berusaha membuat sebuah sistem atau sebuah struktur sendiri untuk membendung pengaruh dari negara super power, negara-negara yang memiliki kekuatan tengah atau middle power yaitu Australia, Kanada, Norwegia dan Swedia. Middle power dapat diketahui melalui kebijakan luar negeri sebuah negara yang mana ditentukan oleh konstitusi atau posisi mereka di sistem dunia (Jordaan, 2003). Terdapat beberapa karakter yang dapat digunakan untuk mengidentifikasi middle power yaitu : pertimbangan kapasitas negara, posisi dalam tatanan 
dunia, komposisi normatif dari masyarakat negara, kepentingan kelas domestik, dan pengaruh asing dalam pembuatan kebijakan.(Jordaan, 2003). Hal-hal yang telah disebutkan tersebut akan digunakan untuk menjelaskan posisi BRICS dalam tatanan sistem internasional. Di dalam jurnal ini penulis menggunakan middle power untuk menjelaskan BRICS National Development Bank sebagai lembaga keuangan internasional, berbeda dengan definisi umum middle power yang menggunakan negara sebagai aktor utama.

\section{HASIL DAN PEMBAHASAN}

\section{International Monetary Fund (IMF)}

Setelah akhir Perang Dunia II para pengambil kebijakan ekonomi negara-negara membicarakan bagaimana membangun kembali perekonomian dunia pasca perang di Bretton Woods. Pertemuan tersebut menghasilkan kesepakatan mengenai upaya pemulihan perekonomian dunia dengan cara mengurangi kebijakan perdagangan, pembayaran, dan nilai tukar yang menghambat perdagangan dunia. Dari pertemuan tersebut disepakati berdirinya tiga lembaga internasional salah satunya yaitu, International Monetery Found (IMF).(Nim, 2011) IMF bertanggung jawab dalam mengatur sistem finansial atau keuangan global serta menyediakan pinjaman kepada negara anggota untuk membantu masalah keuangan negara. IMF akhirnya melalui ratifikasi di DPR atau Kongres negara-negara anggota mulai berdiri pada tanggal 1 Maret 1947.(Nim, 2011) IMF menjadi salah satu Organisasi Internasional Dunia, memiliki anggota sebanyak 187 negara. Garis Komando pelaksanaan IMF berasal dari pemerintah negara anggota. Pengambilan keputusan tertinggi di IMF adalah Dewan Gubernur IMF yang berasal dari seluruh anggota. Dalam operasi sehari-hari, pengambilan keputusan dilakukan oleh Dewan Direksi dan terdiri dari 24 Direktur Eksekutif yang mewakili seluruh negara anggota. Dewan Direksi melakukan pertemuan secara rutin umumnya tiga kali dalam seminggu. Namun rapat juga bisa dilaksanakan diluar tiga hari tersebut setiap terdapat agenda yang dibahas atau permasalahan.(Nim, 2011).

Sesuai dalam pasal 1 dari Article of Agreement, IMF memiliki peran dengan memberi bantuan dana darurat baik berasal dari IMF maupun dari lembaga keuangan internasional lain yang menggunakan IMF sebagai lembaga rujukannya. Terdapat tiga macam jenis bantuan oleh IMF yaitu Fasilitas Umum IMF, Fasilitas Khusus IMF, dan Fasilitas Konsensi IMF.(Nim, 2011) IMF dalam memberi bantuan merupakan lembaga internasional yang 
melakukan pengamanan terhadap pinjaman yang diberikan kepada negara pemohon. Hal ini dilakukan agar dana pinjaman dapat dikembalikan apabila terjadi penarikan sepihak dari persetujuan yang ada. Prinsip ini dikemukakan dalam Anggaran Dasar pendirian IMF, dimana adequate safeguards diperlukan pada setiap pemberian pinjaman. Penarikan dapat dilakukan apabila terjadi kegagalan atau negara pemohon tidak mengikuti persetujuan yang disepakati.(Nim, 2011) Apabila negara meminta bantuan dana kepada IMF, maka negara tersebut diwajibkan untuk memenuhi syarat tertentu sesuai dengan kebijakan IMF. Syarat tersebut mencangkup penyesuaian kebijakan ekonomi domestik negara pemohon. Tujuan hal ini agar negara pemohon bisa segera mengatasi kesulitan neraca pembayaran dan membayar kembali pinjaman yang telah diajukan. Dengan hal ini IMF dapat menanamkan pengaruhnya ke dalam kebijakan negara peminjam dan pengaruh itu akan terus tertanam selama negara peminjam membutuhkan bantuan dana dari IMF. Dapat kita lihat bahwa syarat ini digunakan oleh IMF selain agar dana yang mereka pinjamkan dapat kembali sesuai dengan jangka waktu yang ditetapkan juga untuk menanamkan pengaruh kepada negara peminjam (Nim, 2011).
Penawaran IMF berupa solusi untuk mengatasi permasalahan ekonomi negara-negara semakin lama semakin mengalami goncangan yang disebabkan oleh ketidakdemokratisan yang ada di tubuh IMF. Mekanisme pengambilan keputusan yang tidak didasarkan pada prinsip satu negara satu suara (one man one vote) tetapi lebih didasarkan pada kontribusi dana yang disetorkan anggota. Negara maju seperti Amerika Serikat (19,1\%), Inggris (6,6\%), Jerman (5,7\%), Perancis (4,8\%), Jepang (4,5\%), dan Kanada (3,1\%) memiliki suara yang dominan. Jika dijumlah sebesar 57,6\%, sedangkan negara berkembang hanya 34,4\%.(Nim, 2011) Dengan ketipangan suara yang ada ini, tidak heran jika pemulihan ekonomi dunia cenderung membawa kepentingan negara-negara maju. Dalam hal ini jelas bahwa peran AS cukup besar dalam keputusan penting di IMF. Suara AS sebesar 19,1\% akan mampu menentukan setiap keputusan yang menurut aturan harus memenuhi ketentuan minimal $85 \%$ suara anggotanya. Artinya keputusan di IMF condong membawa kepentingan AS (Widarjono, 2016).

Untuk mencapai sasaran negara saat meminta bantuan terhadap IMF, dalam Konsensus Washington maka negara penerima harus melakukan halhal seperti: (1) pengurangan pengeluaran pemerintah, defisit 
anggaran dan utang luar negeri; (2) pengurangan tingkat pertumbuhan uang untuk mengontrol inflasi; (3) mengurangi peran monopoli pemerintah di pasar atau privatisasi; (4) deregulasi sektor industri dan perbankan; (5) perubahan pemberian kredit dari publik ke sektor swasta; (6) mengurangi kontrol pemerintah terhadap upah, harga suku bunga dan pengurangan subsidi; (7) menaikkan suku bunga; (8) penghapusan hambatan untuk ekspor; penurunan tarif, penghapusan kuota dan menghentikan kontrol devisa dan kontrol nilai tukar; (10) menjaga cadangan devisa dalam jumlah yang aman; (11) melakukan devaluasi. (IMF Site) Dapat dilihat bahwa dalam tiga pilar Konsensus Washington merupakan konspirasi diantara IMF, World Bank, dan Departemen Keuangan AS yang dijadikan acuan IMF sebagai syarat untuk membantu negara-negara yang sedang berkembang (Nim, 2011). Dengan banyaknya syarat yang diajukan, hal itu memunculkan campur tangan terhadap negara-negara penerima yang secara paksa harus menerima nasehat dari IMF. Hal ini dapat menjadi penghalang negara peminjam dalam upaya untuk memiliki kendali atas perekonomiannya sendiri.

IMF telah menjadi alat untuk menerapkan disiplin finansial imperialisme kepada negara-negara dunia menggunakan bantuan teknis. Dalam sejarahnya, IMF mampu menempatkan diri sebagai penasehat ekonomi negara-negara anggotanya khususnya negara miskin. Dengan menggunakan kekuatan yang berasal dari sumber dana iniliah IMF memiliki suatu otoritas untuk mencampuri urusan dalam negeri negara anggota.(Analisis, Sebab, \& Solusinya, 2003) Selain itu IMF juga memiliki kekuatan utama yang terlektak pada perannya sebagai Credit Agency. Hal ini berarti bahwa semua kredit besar di dunia kapitalis maju, baik swasta, pemerintah, ataupun lembaga multilateral seperti Bank Dunia akan menolak meminjamkan uang kepada negara yang tidak mau menerima nasehat dari IMF. IMF adalah keystone dari suatu sistem total yang melibatkan pemerintah dan pasar modal dari seluruh dunia kapitalis (Analisis et al., 2003). Sistem yang dimiliki IMF seperti itu, kurang mendukung peran IMF dalam membantu negara berkembang. Orientasi dan kebijakan IMF cenderung condong terhadap kondisi negara maju dan tidak memikirkan kapasitas yang dimiliki oleh negara berkembang.

\section{BRICS New Development Bank}

$$
\text { Sejarah BRICS New }
$$

Development Bank dimulai dari kesepakatan negara - negara anggota 
BRICS yaitu Brazil, FederasiRussia, India, China, Afrika Selatan sepakat untuk membangun sebuah bank baru yaitu BRICS New Development Bank atau BRICS NDB (Griffith-Jones, 2015). Wacana yang pertama kali terbentuk adalah pada pertemuan BRICS di New Delhi, India tahun 2011 dimana ada sebuah pandangan skeptis mengenai kemampuan anggota - anggota BRICS untuk memenuhi proposal, tidak hanya karena perbedaan yang luas dalam kepentingan - kepentingan yang strategis tetapi juga karena kurangnya kapasitas kelembagaan mengarahkan perbedaan - perbedaan tersebut (Cooper \& Farooq, 2015). Wacana kedua pada Maret 2013 saat pertemuan negara - negara anggota BRICS yang diadakan di Durban, Afrika Selatan (Griffith-Jones, 2014). Pertemuan di Durban telah memunculkan sebuah kesepakatan yang diberinama Durban Summit Declaration and Action Plan (Griffith-Jones, 2014). Isi dari Durban Summit Declaration and Action Plan adalah "Pada Maret 2012 kami mengarahkan Mentri Perdagangan untuk menguji kelayakan untuk pembangunan New Development Bank dengan memobilisasi sumber daya yang ada untuk infrastruktur dan Sustainable Development Projects di dalam BRICS dan ekonomi - ekonomi yang ada pada negara berkembang lainnya, untuk melengkapi upaya yang ada dari institusi - institusi keuangan regional dan multilateral dalam pertumbuhan dan perkembangan global. Kami telah setuju untuk mendirikan New Development Bank. Kontribusi yang ada juga harus besar dan mencukupibagi Bank agar menjadi sarana keuangan atau finansial yang efektif' (Griffith-Jones, 2014). Telah disepakati juga bahwa pemerintahan yang menjalankan NDB atau New Development Bank akan diletakkan di Shanghai, China dan pusat dari regional diletakkan di Afrika Selatan serta President pertama yang akan menjalankan tugas sebagai President New Development Bank selama lima tahun dipilih dari penduduk atau masyarakat India, dan yang terpilih adalah Mr KV Kamath yang dilantik pada Mei tahun 2015 (Griffith-Jones, 2015). Selain itu, ada wacana bahwa President New Development Bank akan dipilih secara bergantian dimana setelah Presiden dari India, maka selanjutnya akan dipilih presiden dengan kewarganegaraan Brazil (Griffith-Jones, 2015). Pembentukan BRICS New Development Bank ini bertujuan untuk meningkatkan hubungan institusional antar anggota BRICS itu sendiri.

New Development Bank memiliki struktur organisasi tersendiri yang terpisah dari struktur organisasi BRICS. Struktur yang ada di BRICS New Development Bank sebagai berikut: 
Gambar 1. Bagan Struktur Organisasi BRICS NDB

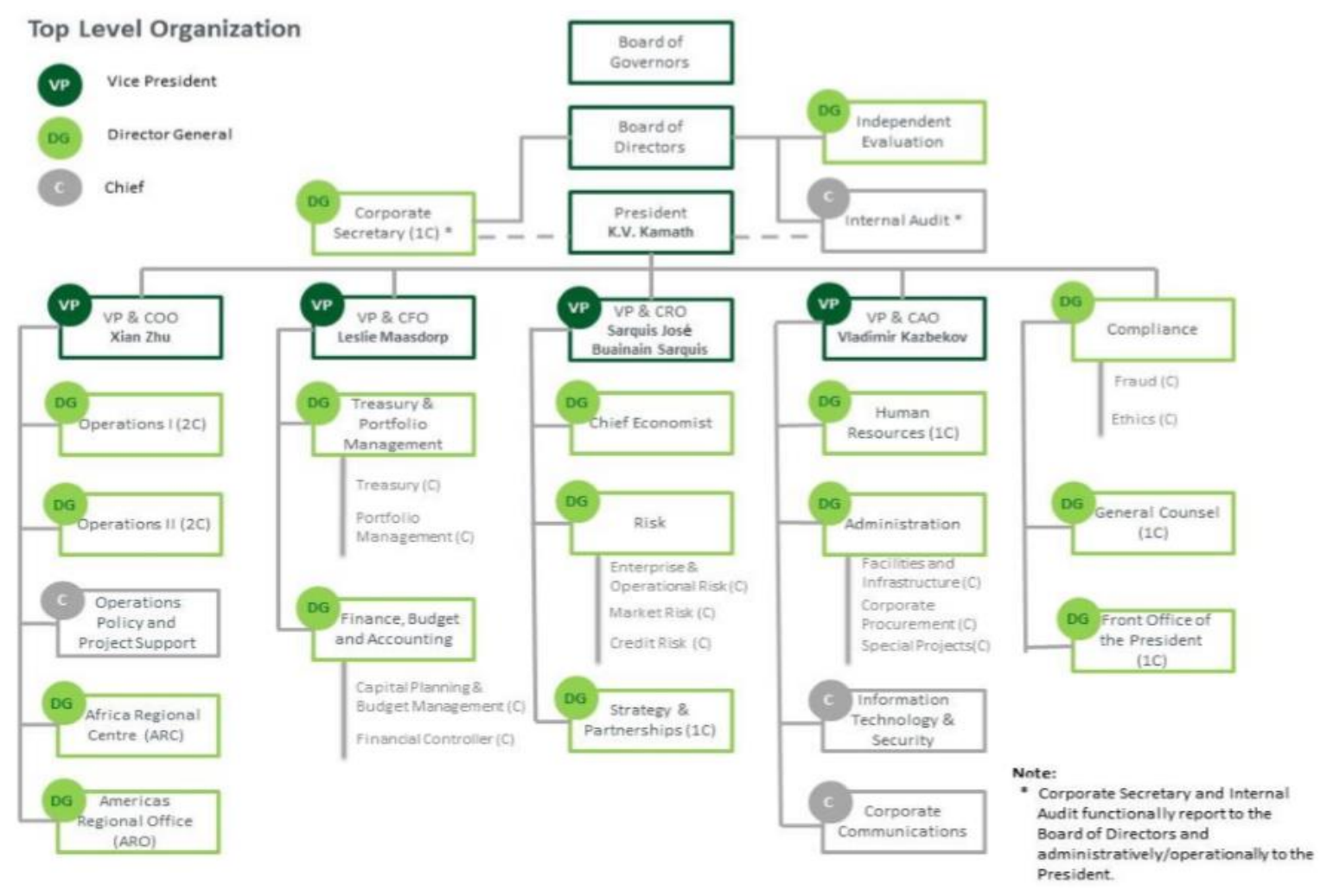

Sumber : www.ndb.int

Komite yang bertugas di BRICS New Development Bank ditunjuk oleh Dewan Direksi untuk memastikan pekerjaan berjalan dengan lancar. BRICS New Development Bank memberikan bantuan kepada negara negara anggota utama dari BRICS itu sendiri dan juga kepada negara negara berkembang diluar BRICS. Dalam beberapa kasus NDB atau New Development Bank akan memberikan bantuan yang berfokus ke Amerika Latin dan juga daerah Afrika karena di Asia sudah terdapat banyak bank yang membantu pembangunan di Asia. Afrika dan Amerika Latin menjadi focus dari BRICS NDB karena misi utama BRICS NDB adalah menghapuskan kesenjangan pembangunan antar negara, dimana dua regional tersebut dirasa kurang mendapatkan perhantian terkait pembangunan infrastruktur, sehingga BRICS NDB datang untuk membantu permasalahan yang ada di Afrika dan Amerika Latin. BRICS NDB menyediakan pinjaman ke jaringan jaringan multilateral, regional, dan juga bank - bank dalam skala nasional yang lain. BRICS NDB juga memberikan investasi berupa infrastruktur untuk membantu pembangunan di negara negara berkembang. BRICS NDB memberikan bantuan - bantuan 
dimana berfokus kepada infrastruktur berkelanjutan yang berfokus di bidang lingkungan, seperti air dan transportasi yang berkelanjutan dan ke depannya akan mulai masuk ke sector energy (Bank, n.d.-b). Pengembangan BRICS NDB dapat memberikan dukungan yang kuat bagi NDB dalam memberikan bantuan - bantuan infrastruktur yang ada bagi negara negara berkembang, dimana semua itu tergantung dari kecepatan pembangunan BRICS NDB itu sendiri, jika pembangunannya cepat maka bisa meningkatkan 'bargaining power' dari BRICS NDB dan juga menyebabkan pemberian bantuan yang dilakukan menjadi berdampak besar (Griffith-Jones, 2015). Negara negara anggota BRICS yang juga menjadi pelopor BRICS NDB sekarang menjadi kontributor besar bagi sistem internasional (School, n.d.). Bantuan dari NDB juga disalurkan ke kegiatan peacekeeping PBB dimana saat negara barat banyak mengurangi bantuannya, BRICS NDB justru memberikan pinjaman yang lebih banyak (School, n.d.).

BRICS NDB mempunyai tujuan utama untuk memobilisasi sumber daya dalam infrastruktur dan proyek pembangunan berkelanjutan di negara - negara anggota BRICS dan juga negara ekonomi berkembang lainnya. Bank seperti BRICS NDB yang bisa dibilang tidak seperti bank - bank tradisional lebih memfokuskan kepada investasi infrastruktur dari pada peminjaman berupa uang. Negara negara yang meminjam tidak perlu mengimplementasikan kebijakan kebijakan yang terkait dengan perubahan di dalam negara mereka seperti kebijakan ekonomi, implementasi reformasi, dan lain lain, yang sering ditetapkan oleh bank bank pembangunan yang tradisional (IMF) (Larionova \& Shelepov, 2016). Perbedaan inilah yang menjadikan NDB memiliki sebuah fitur penting sebagai lembaga yang memastikan sistem keuangan internasional yang lebih adil berdasarkan prinsip menghargai kepentingan semua negara anggota. Selain itu fitur BRICS NDB yang lain adalah adanya keinginan untuk memberikan pinjaman dengan instrumen mata uang nasional di negara berkembang dan juga telah direncanakan di masa depan untuk negara - negara agar bisa membayar pinjaman dengan mata uang lokal mereka walaupun mata uangnya tidak sama dengan yang mereka pinjam.

Secara umum kebijakan kebijakan yang dikeluarkan BRICS NDB digunakan untuk menarik minat peminjam baru dan khususnya ditargetkan untuk negara - negara berkembang secara umum yang membutuhkan pinjaman. Misi utama dari BRICS NDB adalah untuk menyediakan investasi pembangunan 
infrastruktur yang berkelanjutan di negara - negara anggota BRICS yang akan mengurangi kesenjangan pembangunan infrastruktur yang ada. Selain itu, pembangunan infrastruktur juga mempertimbangkan pembangunan berkelanjutan terhadap lingkungan hidup dan iklim yang membutuhkan infrastruktur baru. Infrastruktur yang ada harus dirancang secara kreatif untuk mempromosikan gaya hidup ramah lingkungan serta model pembangunan yang lebih luas. Investasi BRICS NDB dalam bidang infrastruktur yang memungkinkan dalam penggunaan energi terbarukan adalah inisiatif penting untuk mempromosikan pembangunan ramah lingkungan (Griffith-Jones, 2014).

\section{Analisa Peran IMF pada Krisis Ekonomi Indonesia}

Krisis ekonomi yang terjadi di Indonesia pada pertengahan tahun 1997 mengakibatkan meningkatnya utang luar negeri pemerintah maupun swasta. (Khadijah, 2014) Karena kepercayaan masyarakat ekonomi internasional sangat menurun drastis, pada bulan Oktober 1997 secara resmi pemerintah meminta bantuan terhadap IMF.(Salamah, 2001) Krisis yang terjadi tahun 1997 memberikan ampak yang langsung dan terasa membebani Indonesia dengan terjadinya perubahan nilai tukar rupiah terhadap dolar AS secara tajam. Penurunan nilai tukar rupiah yang sangat drastis ini mengakibatkan cadangan devisa pemerintah Indonesia nyaris terkuras habis. (Khadijah, 2014) Sejak ditandatanganinya Letter of Inten (LOI) atau Nota Kesepakatan antara pemerintah Indonesia dan IMF maka mulai saat itulah Indonesia mulai mengandalkan hutang luar negeri. Kucuran dana yang diperoleh dari IMF merupakan andalan utama untuk mengatasi krisis ekonomi yang telah melanda Indonesia saat itu. Pada saat itu IMF dipercaya sebagai dewa penolong yang diharapkan dapat menciptakan stabilitas finansial di Indonesia (Khadijah, 2014).

Permintaan bantuan Indonesia terhadap IMF ini melalui proses perundingan yang cukup panjang dan akhirnya Indonesia mendapatkan bantuan multilateral dari IMF sebanyak US $\$ 23$ milyar. Selain proses yang diperlukan cukup panjang perundingan permintaan bantuan terhadap IMF ini juga cukup alot. Berkaitan dengan adanya perbedaan visi kebijakan IMF yang sangat mungkin tidak sejalan dengan apa yang akan dilakukan pemerintah Indonesia.(Imf, Problematik, \& Hamid, 1997) Hal ini kembali mengacu pada adanya aturan apabila negara meminta bantuan dana kepada IMF, maka negara tersebut diwajibkan untuk memenuhi syarat tertentu sesuai 
dengan kebijakan IMF. Boleh jadi persyaratan yang diajukan IMF tidak cocok dengan yang diinginkan pemerintah Indonesia. Namun, pada saat ini Indonesia masih mampu melunakkan kebijakan persyaratan IMF karena masih mempunyai kekuatan tawar menawar yang lebih baik dibandingkan Thailand yang sepenuhnya dikendalikan dan menerima persyaratan cukup keras dari IMF (IMF et al., 1997).

Akhirnya pada tanggal 15 Januari 1997 Direktur Eksekutif IMF datang ke Jakarta meyodorkan LOI yang ditandatangani oleh Presiden Soeharto dan dimulailah era perekonomian Indonesia yang dimotori oleh IMF. IMF sebagai pihak yang diharapkan mampu mengatasi krisis ekonomi di Indonesia, tentunya tidak semata-mata berdiri sebagai pihak yang hanya "mengucurkan" bantuan uang ke Indonesia tanpa konsekuensi apapun. IMF melalui LOI-nya telah mewajbkan Indonesia untuk mengikuti tahapan pemulihan ekonomi sebagaimana yang telah digariskan dalam perjanjian tersebut. (Khadijah, 2014) Sejak saat itu, semua konsep yang diusulkan pemerintah akhirnya diambil alih oleh IMF. Dalam pelaksanaannya, IMF akan melakukan evaluasi dan perwakilan IMF juga akan masuk ke banyak departemen dan institusi terkait. Melihat hal ini kita dapat menyimpulkan bahwa IMF lah yang mengendalikan sekaligus mendikte strategi kebijakan pemerintah Indonesia.

IMF telah menekan dan menuntut pemerintah Indonesia untuk mematuhi syarat-syarat yang ada dalam LOI dengan begitu dana akan diberikan jika syarat telah terpenuhi. (Khadijah, 2014) Dari berbagai butir yang ditawarkan IMF kepada pemerintah Indonesia, ada tiga jurus yang dikenal dalam mengatasi krisis ekonomi. Tiga jurus itu adalah (1) Jurus Liberalisasi Perdagangan (2) Jurus Privatisasi BUMN (3) Jurus kebebasan investasi modal asing. Jika dilihat rumusan resep yang diberikan IMF terhadap Indonesia nampaknya akan sangat bagus. Namun jika dikaji secara lebih dalam akan terdapat banyak pertentangan. Dengan IMF menajurkan liberalisasi perdagangan bagi negara berkembang maka berarti negara tersebut harus sangat terbuka terhadap arus impor. Dengan masuknya arus impor justru akan membahayakan negara. Untuk butir 2 dan 3, derasnya aliran masuk investasi asing justru akan mengeluarkan biaya untuk melayani investasi asing jauh lebih tinggi dibandingkan utang luar negeri. Semakin besar aliran investasi akan semakin meningkatkan intensitas import dalam negara tersebut. Suntikan bantuan dana dari IMF terus dilakukan dengan harapan pemulihan 
ekonomi, tapi yang terjadi hal itu tidak kunjung terwujud.

Faktor kegagalan IMF di Indonesia sejak keterlibatannya dalam krisis pada tahun 1997 dikarenakan IMF selalu memaksakan pengetatan fiksal dan moneter. Pengetatan tersebut dipaksakan agar ada surplus untuk membayar beban peningkatan utang, padahal tiap negara memiliki struktur ekonomi dan masalah yang berbeda. (Khadijah, 2014) Selama ini program pemulihan krisis yang dijalankan dengan resep IMF menuai berbagai kritik. Usaha yang dilakukan IMF masih berfokus pada upaya peningkatan kemampuan membayar hutang. IMF juga tidak banyak berperan dalam mendorong pemulihan ekonomi yang lebih sustainable tapi lebih banyak menciptakan ketergantungan berkelanjutan. Resep dari IMF juga dianggap terlalu generik, cenderung berorientasi terhadap negara barat dan tidak adaptif terhadap kondisi negara yang meminta bantuan (Salamah, 2001).

\section{Analisa Bantuan BRICS New Development Bank pada India}

Proyek yang BRICS New Development Bank danai di India bernama Proyek Mumbai Metro Rail Project. Tujuan dari proyek ini adalah untuk mengembangkan jalur transportasi di Mumbai yang notabennya merupakan kota terbesar kedua di dunia. Hal ini dikarenakan kapasitas angkutan umum di Mumbai yang masih jauh dari kata cukup untuk memenuhi peningkatan permintaan masyarakat (B. N. D. Bank, 2018). Selain itu, juga untuk mengikuti tren urbanisasi yang diperkirakan terus berlanjut dan populasi di Kota yang diharapkan akan meningkat sebesar 53\% pada tahun 2050 (B. N. D. Bank, 2018). Sehingga proyek dirancang untuk meningkatkan infrastruktur transportasi perkotaan di Mumbai melalui pembiayaan tiga jalur metro, hingga akhirnya mendukung pengembangan kota yang berkelanjutan (B. N. D. Bank, 2018). Proyek ini sejalan dengan Mandat NDB untuk mendukung pembangunan infrastruktur yang berkelanjutan. Total panjang jalur yang akan dibangun yaitu $58 \mathrm{~km}$ dengan membangun jalur 2A dari Dahisar Timur ke DN Nagar, Jalur 2B dari DN Nagar ke Mandale, dan jalur 7 dari Andheri Timur ke Dahisar Timur (B. N. D. Bank, 2018). Selain itu, dalam proyek ini juga menyediakan fasilitas angkutan massal yang berupa rel kereta api ke daerah-daerah terpencil.

Biaya proyek ini mencapai USD 2.500, namun NDB hanya membiayai sebesar USD 260 juta yaitu sekitar 10\% dari total proyek (B. N. D. Bank, 2018). Sedangkan sisa kekurangannya akan di biayai oleh Bank lain dan dari 
Otoritas Pengembangan Wilayah Metropolitan Mumbai. Diperkirakan proyek ini akan selesai pada tahun 2022 (B. N. D. Bank, 2018). BRICS NDB memberikan bantuan infrastruktur kepada India untuk mempercepat pembangunan atau proyek yang ada di India. Pembangunan ini bisa berpengaruh ke sektor lain seperti ekonomi agar ekonomi di India bisa meningkat dengan pesat dan bisa meningkatkan sektor yang lain juga.

\section{Perbandingan Bantuan yang Diberikan oleh IMF dan BRICS New Development Bank}

IMF sebagai bank internasional yang sudah lama memberikan bantuan untuk perkembangan negara - negara di dunia, khususnya di bidang ekonomi. Bantuan yang diberikan IMF adalah bantuan finansial untuk digunakan negara peminjam memperbaiki atau memulihkan ekonomi negara - negara peminjam yang dulu difokuskan untuk negara korban perang dunia II, namun sekarang sudah menyeluruh. Pinjaman yang diberikan IMF tidak cuma cuma, IMF memberikan beberapa persyaratan sebelum memberikan pinjaman. Persyaratan yang diberikan IMF harus disetujuan oleh negara yang ingin meminjam, jika tidak maka tidak akan diberikan pinjaman oleh IMF. Persyaratan oleh IMF berisfat mengikat dan memaksa, serta seringkali mempengaruhi kebijakan perekonomian di negara peminjam. Persyaratan yang diajuikan seringkali hanya menguntungkan IMF karena membawa kepentingan negara dengan kontribusi dana terbesar di IMF yaitu AS. IMF juga mempengaruhi kebijakan negara peminjam bukan hanya dengan persyaratan persyaratan yang diajukan, tetapi juga IMF diwajibkan untuk menjadi penasihat ekonomi negara peminjam, hal ini menunjukkan peran kapitalis IMF sangatlah kuat.

BRICS NDB sendiri berbeda dengan IMF, BRICS NDB memberikan pinjaman tidak dalam sektor finansial, namun lebih ke investasi infrastruktur di suatu negara. Peminjaman di BRICS NDB juga tidak dipersulit oleh persyaratan persyaratan yang ada, selama negara peminjam bisa mengembalikannya, persyaratan lain tidak menjadi masalah bagi BRICS NDB mengingat negara anggota BRICS sendiri memiliki banyak perbedaan dalam kebijakan ekonomi sehingga tidak ada dominasi yang kuat oleh suatu negara. Tidak adanya dominasi oleh suatu negara menyebabkan mata uang yang dipinjamkan tergantung mata uang nasional negara yang meminjamkan. Peminjaman juga bisa dikembalikan sesuai dengan mata uang nasional negara peminjam sehingga tidak 
terpaku pada satu mata uang yang sama, berbeda dengan IMF yang menggunakan mata uang Dollar Amerika sebagai mata uang internasional. BRICS NDB mempermudah syarat peminjaman karena ingin menarik peminjam peminjam baru agar mereka beralih ke BRICS NDB dan tidak tergantung dengan IMF lagi. Negara - negara BRICS sendiri merupakan negara dengan middle power dengan pertumbuhan ekonomi yang pesat dan perbedaan sistem peminjaman yang lebih mudah oleh BRICS NDB membuat mereka siap untuk menyaingi dominasi IMF selama ini.

\section{KESIMPULAN}

International Monetary Fund dan BRICS New Development Bank merupakan dua organisasi internasional yang berbasiskan pada ekonomi. Kedua organisasi tersebut tentunya memiliki beberapa perbedaan. Salah satu perbedaan yang menonjol adalah negara-negara yang terlibat di dalamnya. Dapat dilihat, sebagai organisasi yang lebih lama berkecimpung dalam dunia internasional, IMF memiliki lebih banyak kolega. Diantara kolega-kolega tersebut, kebanyakan adalah dari negara yang sudah maju dalam bidang perekonomiannya. Dapat dilihat dari sistem pengambilan suara seperti prinsip satu negara satu suara (one man one vote) tetapi lebih didasarkan pada kontribusi dana yang disetorkan anggota. Negara maju seperti Amerika Serikat (19,1\%), Inggris $(6,6 \%)$, Jerman (5,7\%), Perancis $(4,8 \%)$, Jepang (4,5\%), dan Kanada (3,1\%) memiliki suara yang dominan. Jika dijumlah sebesar $57,6 \%$, sedangkan negara berkembang hanya 34,4\%. Atas dasar hal tersebut, IMF dinilai sebagai organisasi yang dikuasai oleh kalangan atau kelas atas. Selain itu, dalam hal peminjaman uang, IMF juga memberlakukan beberapa syarat khusus bagi negara yang akan meminjam uang ke IMF. Syarat-syarat tersebut harus dipenuhi oleh negara terkait agar dapat menerima bantuan dana dari IMF. Tidak jarang juga syarat-syarat tersebut lebih banyak menguntungkan negara-negara maju yang menjadi anggota IMF.

Berbeda dengan IMF, BRICS NDB mempunyai tujuan utama untuk memobilisasi sumber daya dalam infrastruktur dan proyek pembangunan berkelanjutan di negara - negara anggota BRICS dan juga negara ekonomi berkembang lainnya. Berangkat dari negara-negara pendiri BRICS yang notabene adalah negara berkembang, BRICS NDB lebih fokus terhadap pembangunan negara-negara berkembang. BRICS sendiri didirikan atas dasar rasa tidak terima dan ingin lepasnya negara-negara seperti Brasil, Rusia, India, Cina, dan Afrika Selatan 
atas monopoli uang yang dilakukan negara-negara maju melalui organisasiorganisasi keuangan seperti IMF. Negara-negara tersebut sangat ingin lepas dari belenggu negara-negara adidaya yang telah merugikan dan menghambat kemajuan negara-negara berkembang. Oleh karena itu, BRICS NDB hadir dengan menawarkan bantuan-bantuan keuangan, beserta persyaratan yang tidak memberatkan peminjam. Serta diatur atau dikelola oleh negara-negara yang masih samasama belajar dan tidak berusaha untuk saling menghegemoni satu sama lain

Dapat disimpulkan dengan menggunakan teori strukturalis bahwa dominasi yang dibangun IMF dalam sistem moneter Internasional selama ini telah menciptakan struktur dalam sistem internasional. Penggunaan konsep Middle Power berperan disini, dimana BRICS NDB membuat sebuah sistem yang baru yang berisikan negara - negara yang memiliki kekuatan dibawah dari super power ingin membendung pengaruh yang diberikan. BRICS NDB menjadi sebuah sistem baru yang lebih disukai negara - negara di dunia dan berpotensi bersar untuk menggantikan IMF sebagai institusi moneter internasional.

\section{REFERENSI}

Bank, B. N. D. (2018) Project Summary for Public Disclosure.
Bank, N. D. (2019) Leadership (Online).

Tersedia di:

https://www.ndb.int/about-

us/organisation/governance/ (Diakses: 30 April 2019).

Geall, Sam. (2013 New perspectives on the new BRICS (Online). Tersedia di: https://dialogochino.net/wpcontent/uploads/2019/01/BRICS_en. pdf (Diakses: 30 April 2019).

Susilo, Basis. (2001) "Bantuan Ekonomi IMF terhadap Indonesia", Jurnal Hubungan Internasional, Vol. 1 No. 1, pp. 27-29.

BBC. (2014) BRICS Nations to Create $\$ 100 B N$ Development Bank (Online). Tersedia di: https://www.bbc.com/news/business28317555 (Diakses: 22 April 2019).

Cooper, A. F., \& Farooq, A. B. (2015) "Testing the Club Dynamics of the BRICS: The New Development Bank from Conception to Establishment", International Organisation Research Journal, 10(2), pp. 1-15.

Culpepper, P. D. (2015) "Structural power and Political Science in the Post-Crisis Era", Business and Politics, 17(3), 391-409 (Online). Tersedia di: https://doi.org/10.1515/bap-20150031 (Diaskes 17 April 2019).

Griffith-Jones, S. (2014) "A BRICS Development Bank: A Dream Coming True?", Discussion Papar UN Conference on Drade and Development, March, No. 215.

Griffith-Jones, S. (2015) Financing Global Development: The BRICS New Development Bank (Online). Tersedia di: https://www.diegdi.de/uploads/media/BP_13.2015.pdf (Diakses: 22 April 2019).

Hardoko, E. (2018) Hari ini dalam Sejarah: AS Bangun Kembali Eropa Lewat Marshall Plan," (Online). Tersedia di: https://internasional.kompas.com/read /2018/04/03/14152061/hari-inidalam-sejarah-as-bangun-kembali- 
eropa-lewat-marshall-plan (Diakses: 22 April 2019).

Harmen, R. (2011) Analisis Peran IMF (International Monetery Fund) Dalam Privatisasi BUMN di Indonesia Studi Kasus : Privatisasi PT. Indosat, Tbk. Skripsi. Jakarta: Ilmu Hubungan Internasional UIN Syarif Hidayatullah.

International Monetery Fund (IMF). (t.t) Origins, Purpose (Online). Tersedia di: http://www.imfsite.org (Diakses: 2 April 2019).

Jordaan, E. (2003) "The Concept of A Middle Power In International Relations: Distinguishing Between Emerging And Traditional Middle Powers," Politikon, 30(1), 165-181 (Online). Tersedia di: https://doi.org/10.1080/02589340320 00147282 (Diakses: 22 April 2019).

Khadijah, S. (2014) "IMF Dalam Perspektif Teori Dependensi dalam Perubahan," Jurnal Makna, Vol. 4, No. 2.

Larionova, M. V, \& Shelepov, A. V. (2016) New Development Bank and Asian Infrastruct in the Global Fi Nancial System, pp. $702-718$ (Online). Tersedia di: https://doi.org/10.22363/2313 (Diakses: 22 April 2019).

Mas'oed, M. (1995) Studi Hubungan Internasional: Tingkat Analisis dan Teorisasi. Yogyakarta: Universitas Gadjah Mada
May, C. (2008) "Strange Fruit: Susan Strange's Theory of Structural Power in the International Political Economy", Global Society, 10(2), pp. 167-189

(Online). Tersedia di: https://doi.org/10.1080/13600829608 443105 (Diakses: 23 April 2019).

Powell, A. (2013). BRICS Leaders Optimistic About New Development Bank (Online). Tersedia di: https://www.voanews.com/africa/bric s-leaders-optimistic-about-newdevelopment-bank (Diakses: 23 April 201).

Prapti, E.S. (2003) "Problematika Opsi Pembayaran Kembali Pinjaman Extended Fund Facilities-IMF: Suatu Analisis Ekono-Politik tentang Sebab Akibat dan Skenario Solusinya", Unisia Jurnal Ilmu-ilmu Sosial, No. 50, pp. 353360.

Salamah, L. (2001) "Lingkaran Krisis Ekonomi Indonesia. Masyarakat, Kebudayaan dan Politik, (2), pp. 65-76.

Steans, J., Pettiford, L., \& Diez, T. (2005). Introduction to International Relations, Perpectives, \& Themes. London: Pearson \& Longman.

Widarjono, A. (2016) "Evaluasi Kritis Kinerja IMF dalam Krisis Asia Unisia Jurnal Ilmu-ilmu Sosial, 26(50), pp. 343352 (Online). Tersedia di: https://doi.org/10.20885/unisia.vol26.i ss50.art2 (Diakses: 20 April 2019). 